\title{
DERMATOPHYTE AGENTS IN THE CITY OF SÃO PAULO, FROM 1992 TO 2002
}

\author{
Patricia Augusta Vianna CHINELLI(1), Alexandre de Abreu SOFIATTI(1), Ricardo Spina NUNES(2) \& Jose Eduardo da Costa MARTINS(2)
}

\begin{abstract}
SUMMARY
Dermatophytosis are superficial mycoses caused by fungi that can invade stratum corneum and keratinized tissues. In order to study the frequency of dermatophytes species and the clinical manifestations caused by these fungi, in São Paulo, SP, Brazil, the authors analyzed cultures isolated at the Mycology Laboratory from a selected population (15,300 out-patients of the Hospital das Clínicas, Department of Dermatology, Faculty of Medicine of University of São Paulo) from January 1992 to June 2002.

The most prevalent dermatophyte was Trichophyton rubrum (48.7\%), followed by Microsporum canis (20.9\%), Trichophyton tonsurans (13.8\%), Trichophyton mentagrophytes (9.7\%), Epidermophyton floccosum (4.1\%), and Microsporum gypseum (2.5\%). These agents determined more than one clinical manifestation, i.e., tinea corporis (31.5\%), tinea capitis (27.5\%), tinea unguium $(14.8 \%)$, tinea cruris $(13.9 \%)$, tinea pedis $(9.9 \%)$, and tinea manuum (1.9\%). Clinical variants of dermatophytosis and their relationship to the etiologic agents were studied and the results were compared to those obtained in previous studies in other regions of Brazil and in other countries.
\end{abstract}

KEYWORDS: Dermatophytosis; Dermatophyte; Tinea; Selected population; Frequency.

\section{INTRODUCTION}

Dermatophytes are a group of fungi that, during their parasitic life, utilize keratin as a substrate, infecting the skin, hairs and nails and thereby cause superficial mycoses in humans and animals ${ }^{51}$. They are universally distributed and may be categorized as geophilic, zoophilic and anthropophilic depending on their natural habitat ${ }^{2,20,43}$. According to the morphological characteristics of the aleuriospores they are classified in three anamorphic genera: Trichophyton, Epidermophyton and Microsporum ${ }^{11}$. Teleomorphs of dermatophytes are classified in the genus Arthroderma ${ }^{16}$.

During the evolution of dermatophytes, more species have evolved a dependency on human infection than on any other species of animals. This probably is a result of our soft "naked" stratum corneum, the wearing of clothing and shoes and our gregarious behavior"

Dermatophytosis are fungal infections commonly occurring in tropical countries, often representing a public health problem. The distribution and frequency of dermatophytosis and their etiologic agents vary according to the geographic region studied, the socio-economic level of the population, the time of study, the climatic variations, the presence of domestic animals, and age $\mathrm{e}^{45}$.
This study investigated the frequency of dermatophyte species and the clinical variants of dermatophytosis in São Paulo City, São Paulo, Brazil, during the period from 1992 to 2002.

\section{MATERIALS AND METHODS}

A total of 15,300 cases of superficial mycotic infections were diagnosed during the period from January 1992 to June 2002. Specimens were collected from ambulatory patients attended in the Mycology Laboratory of Department of Dermatology of Hospital das Clínicas. Skin, nail scrapings, and broken hairs were clarified in $10 \%$ potassium hydroxide plus dimethyl sulfoxide for microscopic examination. Cultures were performed only when asked by the clinician. The specimens were inoculated on slant tubes of Sabouraud-dextrose agar with chloramphenicol and cycloheximide (Mycobiotic agar, Difco), and incubated at room temperature for two weeks or more and discarded.

The identification of dermatophytes was based on the macro and microscopic characteristics of their colonies grown on routine medium or special medium for diagnosis.

Six clinical variants were considered: tinea capitis, tinea corporis, tinea cruris, tinea manuum, tinea pedis, and tinea unguium. 


\section{RESULTS}

All the mycological exams carried out on 15,300 patients with clinically suspected dermatophytosis were positive, but only 655 dermatophyte strains were recovered. Reduced number of isolates may be explained by the small number of requisition for cultures, bacterial contamination of clinical specimens, cases of chronic dermatophytosis with a long time therapy or therapy control. In the study of bacterial contamination of primary isolates, it was found that the major species isolated with dermatophytes were Pseudomonas aeruginosa, which showed inhibitory properties on the growth of species of dermatophytes ${ }^{21}$.

Among the species isolated, T. rubrum was the most frequent (48.7\%), followed by M. canis (20.9\%), T. tonsurans (13.8\%), T. mentagrophytes (9.7\%), E. floccosum (4.1\%), and M. gypseum (2.5\%) (Table 1).

Table 1

Epidemiological classification of dermatophytes species isolated at Mycology Laboratory (from January 1992 to June 2002)

\begin{tabular}{llcccc}
\hline Groups & Agents & Cultures & $\%$ & Total & $\%$ \\
\hline Anthropophilic & T. rubrum & 319 & $(48.7)$ & 501 & $(76.4)$ \\
& T. tonsurans & 91 & $(13.8)$ & & \\
& T. mentagrophytes & 64 & $(9.7)$ & & \\
& E. floccosum & 27 & $(4.1)$ & & \\
Zoophilic & M. canis & 137 & $(20.9)$ & 137 & $(20.9)$ \\
Geophilic & M. gypseum & 17 & $(2.5)$ & 17 & $(2.5)$ \\
\hline
\end{tabular}

As shown in table 2, among the clinical variants, tinea corporis comprised $31.9 \%$ of cases, while tinea capitis was observed in $27.5 \%$ of cases, tinea ungueum was involved in $14.8 \%$, tinea cruris in $13.9 \%$, tinea pedis in $9.9 \%$ and tinea manuum in $1.9 \%$. Regarding correlation of the clinical variant with the etiological agent, results indicated that the major agent of tinea capitis was $M$. canis $(65.0 \%)$, followed by $T$. tonsurans (28.3\%). Tinea corporis was predominantly caused by $T$. rubrum $(69.4 \%)$, followed by $T$. tonsurans, $M$. canis, and T. mentagrophytes $(8.6 \%, 7.2 \%$ and $6.2 \%)$. In tinea cruris cases, T. rubrum was the most prevalent
(67.0\%), followed by E. floccosum (18.7\%). T. rubrum prevailed on the hands $(61.5 \%)$, followed by $T$. tonsurans $(15.3 \%)$. The main etiological agent of tinea pedis and tinea unguium was T. rubrum $(56.9 \%$ and $67.0 \%$, respectively), followed by $T$. mentagrophytes $(30.7 \%$ and $18.5 \%$, respectively).

Of the patients studied, $377(57.5 \%)$ were male and $278(42.4 \%)$ female, and in the majority of them the clinical features but not the age was recorded. As shown in the table 3, a correlation of frequency of clinical variants and sex, it was found a significant prevalence of tinea corporis $(59.8 \%)$, tinea cruris $(80.2 \%)$, tinea pedis $(64.6 \%)$ and tinea manuum $(69.2 \%)$ in male sex than in females. A frequency of tinea unguium, with $59.7 \%$ predominated in females but in tinea capitis the frequency is the same in both sexes.

Table 3

Clinical variants according to the sex of the patients

\begin{tabular}{lrrrrr}
\hline \multirow{2}{*}{ Clinical variant } & \multicolumn{4}{c}{ Sex } & \multirow{2}{*}{ Total } \\
\cline { 2 - 5 } & \multicolumn{2}{c}{ Male } & \multicolumn{2}{c}{ Female } & \\
\hline tinea corporis & 125 & 59.8 & 84 & 40.1 & 209 \\
tinea capitis & 89 & 49.4 & 91 & 50.5 & 180 \\
tinea unguium & 39 & 40.2 & 58 & 59.7 & 97 \\
tinea cruris & 73 & 80.2 & 18 & 19.7 & 91 \\
tinea pedis & 42 & 64.6 & 23 & 35.3 & 65 \\
tinea manuum & 9 & 69.2 & 4 & 30.7 & 13 \\
Total & 377 & 57.5 & 278 & 42.4 & 655 \\
\hline
\end{tabular}

\section{DISCUSSION}

In the last decade (1992 to 2002), six dermatophyte species were detected as dermatophytosis agents in São Paulo City: T. rubrum, T. mentagrophytes, M. canis, E. floccosum, T. tonsurans, and M. gypseum. The predominance of T. rubrum $(48.7 \%)$ represents a worldwide trend and the present data are consistent with those reported in studies carried out in the South, Southeast, Center-West and Northeast regions of Brazil $^{8,12,13,14,28,29,30,38,46,47}$.

Studies conducted in European countries, United States of America,

Table 2

Frequency of clinical variants and distribution of dermatophyte species

\begin{tabular}{|c|c|c|c|c|c|c|c|c|c|c|c|c|c|c|}
\hline \multirow{3}{*}{ Clinical variant } & \multicolumn{12}{|c|}{ Dermatophyte species } & \multirow{2}{*}{\multicolumn{2}{|c|}{ Total \% }} \\
\hline & \multicolumn{2}{|c|}{ T. rubrum } & \multicolumn{2}{|c|}{ M. canis } & \multicolumn{2}{|c|}{ T. tonsurans } & \multicolumn{2}{|c|}{ T. mentagrophytes } & \multicolumn{2}{|c|}{ E. floccosum } & \multicolumn{2}{|c|}{ M. gypseum } & & \\
\hline & No. & $\%$ & No. & $\%$ & No. & $\%$ & No. & $\%$ & No. & $\%$ & No. & $\%$ & No. & $\%$ \\
\hline tinea corporis & 145 & 69.4 & 15 & 7.2 & 13 & 8.6 & 13 & 6.2 & 8 & 3.8 & 10 & 4.8 & 209 & 31.9 \\
\hline tinea capitis & 3 & 1.7 & 117 & 65.0 & 51 & 28.3 & 6 & 3.3 & - & & 3 & 1.7 & 180 & 27.5 \\
\hline tinea unguium & 65 & 67.0 & 2 & 2.1 & 9 & 9.3 & 18 & 18.5 & 1 & 1.0 & 2 & 2.1 & 97 & 14.8 \\
\hline tinea cruris & 61 & 67.0 & 1 & 1.1 & 5 & 5.5 & 6 & 6.6 & 17 & 18.7 & 1 & 1.1 & 91 & 13.9 \\
\hline tinea pedis & 37 & 56.9 & 1 & 1.5 & 6 & 9.2 & 20 & 30.7 & - & & 1 & 1.5 & 65 & 9.9 \\
\hline tinea manuum & 8 & 61.5 & 1 & 7.7 & 2 & 15.3 & 1 & 7.7 & 1 & 7.7 & - & & 13 & 1.9 \\
\hline Total Dermatophytes sp. \% & 319 & 48.7 & 137 & 20.9 & 91 & 13.9 & 64 & 9.7 & 27 & 4.1 & 17 & 2.6 & 655 & \\
\hline
\end{tabular}


Mexico and Argentina, also confirm the higher percentage of isolation

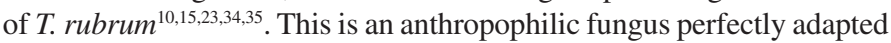
to human keratinized tissues causing a mild chronic inflammation and rarely infects animals ${ }^{49}$. There have been only a few reports of its isolation from animals (cats, dogs, calves) ${ }^{22,37,43,50,52}$. Transmission of T. rubrum probably occurs directly from humans to animals ${ }^{26}$. The frequency of this agent increases with the process of urbanization, leading to its predominance as an agent causing dermatophytosis in large urban centers $^{42}$.

Since 1965, T. rubrum has become the predominant species, being more frequent than $M$. canis and being isolated from as many as $65.5 \%$ of dermatophytosis cases in São Paulo ${ }^{14,29,46}$. In the present study, this percentage was decreased to $48.7 \%$, but the species persists as the leading agent.

The prevalence of the zoophilic fungus $M$. canis has been decreased in developed countries and in most of the states of Brazil ${ }^{14,29,30,46}$. It is a species adapted to domestic animals such as dogs, cats, cattle or horses which can infect persons who have contact with these animals in the domestic environment ${ }^{24,42}$. It is responsible for most scalp infections, being the predominant agent detected at this region in most studies ${ }^{12,13,14,15,18}$. In the present study it was the second most frequent species, in agreement with the trend reported in a previous study conducted in São Paulo ${ }^{46}$ and in European studies conducted in Spain, Greece and Italy ${ }^{9,35,39}$. In other regions, the frequency of $M$. canis varies, with the species being the third most frequent one in Rio Grande do Sul and Goiás (Brazil) and Argentina ${ }^{12,13,15,31}$, and being present at reduced percentages in Colombia and in the Amazon region $6,40,41$.

T. tonsurans is an anthropophilic dermatophyte brought to the American continent by Spanish and Portuguese colonizers, which causes epidemics in schools, day-care-centers and asylums. T. tonsurans is a cosmopolitan fungus that causes an endothrix infection of hair and its distribution is worldwide. In the present study, T. tonsurans was the third most frequent species, predominantly causing lesions on the scalp. In South region of Brazil, T. tonsurans was rarely isolated ${ }^{29,30,31,32,48}$, although it was responsible for microepidemics in Rio Grande do $\mathrm{Sul}^{33}$. In the North and Northeast regions, this agent is the most prevalent in scalp infections $s^{4,6,40,41}$. When it finds favorable environmental conditions it becomes settled as an endemic species. T. tonsurans is most commonly found in Central and Southern Europe, U.S.S.R. and Central and South America $^{24}$. In the United States, the fungus predominates in scalp infections $\mathrm{s}^{23,25,54}$. Infections in humans are often acquired from contact with animals, environment or person-to-person spread ${ }^{24}$.

T. mentagrophytes can be both anthropophilic and zoophilic. The fungus is cosmopolitan ${ }^{1}$ and is one of the most common dermatophytes infecting man and animals. Infections in humans are often acquired to contact with soil and domestic animals or others, such as cattle, horses and birds ${ }^{17}$.

T. mentagrophytes was the fourth species most frequently detected in the present study, mainly involving hands and nails. In other Brazilian studies carried out at different times, this species was the second most common ${ }^{8,12,13,31,32,36}$ and occasionally predominated in tinea pedis ("athlete's foot") $8,12,13,31,32,36$.

Epidermophyton floccosum is an anthropophilic fungus, ubiquitous ${ }^{1}$ which attacks the skin and nails of man. Infections are more common in the tropics affecting males and children ${ }^{7}$. Animal infections are rare ${ }^{2,51,53}$.

E. floccosum in our study was the fifth most frequent species of dermatophytes and was the predominant cause of tinea cruris. In Western Europe this species is a major cause of tinea cruris and tinea pedis. Its frequency has been decreasing unlike the increasing incidence of $T$. rubrum, although data from Italy showed that it is still a prevalent agent among the dermatophytosis? .

Microsporum gypseum is a geophilic fungus found worldwide, frequently isolated from soil, and being seldom detected as an agent of superficial mycoses that commonly infect humans ${ }^{1}$. It is relatively rare in the United States, United Kingdom and Germany, but common in South America ${ }^{1}$.

M. gypseum frequency was the least and observed mainly in cases of tinea corporis. Tinea pedis and tinea manuum are seen commonly, but tinea unguium is rare.

In the present study, no other agents such as Trichophyton violaceum, Trichophyton verrucosum or Trichophyton schoenleinii were isolated, confirming a trend observed in the latest studies carried out in São Paulo $^{14,46}$. Except for tinea capitis, T. rubrum was the dermatophyte most frequently isolated in all the variants of infection: tinea corporis $(69.4 \%)$, tinea cruris and tinea unguium $(67.0 \%)$, tinea manuum $(61.5 \%)$, and tinea pedis $(56.9 \%)$. It is interesting to note that in regions of low urbanization the frequency of T. rubrum is lower and may even be nonexistent, as is the case for the Amazon region ${ }^{40,41}$, confirming once again the predominance of this anthropophilic fungus in urban centers

About tinea corporis, the second most frequent agent is $T$. tonsurans (8.6\%), followed by M. canis (7.2\%) and T. mentagrophytes $(6.2 \%)$.

Infection with $M$. canis is more frequent in the scalp (65.0\%), followed by $T$. tonsurans (28.3\%). This frequency is maintained in most regions of Brazil, except for the Amazon region and some Northeastern cities, where $T$. tonsurans is the most common agent $t^{4,40,41}$. The frequency of tinea capitis increases with poverty, malnutrition, crowding, and large families with precarious hygiene habits, as found in developing countries ${ }^{5}$.

Ringworm of the nails is recorded worldwide, almost many species has been implicated in this infection, the common ones are T. rubrum, $T$. mentagrophytes, E. floccosum and to lesser extent, T. tonsurans and $T$. violaceum $^{55}$.

In the present study $T$. rubrum (67\%) prevailed, followed by $T$. mentagrophytes $(18.5 \%)$. This same order was detected in tinea pedis, with respective frequencies of $56.9 \%$ and $30.7 \%$. These values agree with those reported in the literature ${ }^{12,13,14,15,28,29,30,31,32,46,48}$.

T. rubrum predominated in the inguinal region (67.0\%), followed by E. floccosum (18.7\%), both being anthropophilic agents prevailing in the areas covered by clothing, a fact that makes environmental transmission more difficult.

In conclusion, our data show a predominance of T. rubrum over the remaining agents in all body regions, except for the scalp, where $M$. 
canis predominated. This may be explained by urbanization, which leads to a predominance of anthropophilic fungi as etiologic agents of dermatophytosis because of their better adaptation to human keratinized tissues; the agents may also require a longer time before a cure can be obtained by treatment compared to other zoophilic and geophilic agents ${ }^{27}$.

Dermatophytosis occur more frequently in the genital area of males than in female patients due to the use of tight clothes that give rise a local maceration and obstruction by the scrotum ${ }^{45,53}$. Another site affected more frequently in males are feet and nails caused by the use of nylon stocking and shoes for a long time in a day.

Prevalence of dermatophyte infections may change as a result of many factors, including human migratory patterns, climatic alterations and new therapies ${ }^{1}$, but none of these can adequately explain the current increase of some species like T. rubrum and T. mentagrophytes.

\section{RESUMO}

\section{Agentes de dermatofitoses na Cidade de São Paulo no período de 1992 e 2002}

Dermatofitoses são infecções fúngicas superficiais causadas por agentes capazes de produzir lesões em tecidos queratinizados. Com o intuito de avaliar a epidemiologia e etiologia das infecções causadas por dermatófitos, em pacientes de Ambulatório do Departamento de Dermatologia do Hospital das Clínicas de São Paulo, SP, Brasil, foram analisados os resultados de culturas realizadas pelo Laboratório de Micologia deste Departamento da Faculdade de Medicina da Universidade de São Paulo, no período de janeiro de 1992 a junho de 2002.

O dermatófito isolado com maior freqüência foi o Trichophyton rubrum (48,7\%), seguido por Microsporum canis (20,9\%), Trichophyton tonsurans (13,8\%), Trichophyton mentagrophytes (9,7\%), Epidermophyton floccosum (4,1\%) e Microsporum gypseum (2,5\%). Esses agentes foram responsáveis por diferentes formas clínicas: tinea corporis $(31,9 \%)$, tinea capitis $(27,5 \%)$, tinea unguium $(14,8 \%)$, tinea cruris $(13,9 \%)$, tinea pedis $(9,9 \%)$ e tinea manuum $(1,9 \%)$. Foi analisada a relação, entre as formas clínicas da dermatofitose e os seus respectivos agentes etiológicos, comparando-se os nossos dados com os de estudos semelhantes, em diversas regiões do país e do mundo.

\section{ACKNOWLEDGEMENTS}

The authors are grateful to the head of the Dermatology Department, and their staff for the collaboration in the study. We are especially grateful to Elisabeth Maria Heins-Vaccari and Natalina T. de Melo from Instituto de Medicina Tropical de São Paulo, for review of the manuscript. We thank Claudia de Freitas Caetano for the secretarial work.

\section{REFERENCES}

1. AJELLO, L. - Geographic distributions and prevalence of the dermatophytes. Ann. N. Y. Acad. Sci., 89: 20-38, 1960.

2. ALY, R. - Ecology and epidemiology of dermatophyte infections. J. Amer. Acad. Derm., 31: 521-525, 1994
3. BORO, B.R.; CHACKRABARTY, A.K.; SARMA, G. \& SARMAH, A.K. - Ringworm in animals due to Epidermophyton floccosum. Vet. Rec., 107: 491-492, 1980

4. BRILHANTE, R.S.; PAIXÃO, G.C.; SALVINO, L.K. et al. - Epidemiology and ecology of dermatophytosis in the City of Fortaleza: Trichophyton tonsurans as important emerging pathogen of Tinea capitis. Rev. Soc. bras. Med. trop., 33: 417-425, 2000.

5. BUGINGO, G. - Dermatophytic infection of the scalp in the region of Butare (Rwanda). Int. J. Derm., 22: 107-108, 1983.

6. BUITRAGO, G.E. - Dermatomicosis en población de Manizales. Biomédica, 14: 77-84, 1994.

7. CABRITA, J. \& FIGUEIREDO, M.M. - Dermatophytes in Portugal. Sabouraudia, 11: 21-29, 1973.

8. CAMPBELL, I.; CAMPBELL, G.; AGUIRRE, L. \& SANTOS, M.G. - Dermatófitos em Brasilia. An. bras. Derm., 59: 224-225, 1984.

9. CARETTA, G.; DEL FRATE, G.; PICCO, A. M. \& MANGIAROTTI, A.M. - Superficial mycoses in Italy. Mycopathologia (Den Haag), 76: 27-32, 1981.

10. CHMEL, L. \& BUCHVALD, L. - Ecology and transmission of Microsporum gypseum from soil to man. Sabouraudia, 8: 149-156, 1970.

11. CLAYTON, Y.M. \& MIDGLEY, G. - Identification of agents of superficial mycoses. In: EVANS, E.G.V. \& RICHARDSON, M.D., ed. Medical Mycology. A practical approach. Oxford, Oxford University Press, 1989.

12. COSTA, M.; PASSOS, X.S.; SOUZA, L.K.H. et al. - Epidemiologia e etiologia das dermatofitoses em Goiânia, GO, Brasil. Rev. Soc. bras. Med. trop., 35: 19-22, 2002.

13. COSTA, T.R.; COSTA, M.R.; SILVA, M.V. et al. - Etiology and epidemiology in dermatophytosis in Goiânia, State of Goiás, Brazil. Rev. Soc. bras. Med. trop., 32: 367-371, 1999.

14. CUCÉ, L.C.; CASTRO, R.M.; DINATO, S.L.M. \& SALEBIAN, A. - Flora dermatofítica em São Paulo (1964-1974). An. bras. Derm., 50: 141-146, 1975.

15. DAVEL, G.; PERROTA, D.; CANTEROS, C. et al. - Multicenter study of superficial mycoses in Argentina. EMMS Group. Rev. argent. Microbiol., 31: 173-181, 1999.

16. DAWSON, D.C. \& GENTLES, J.C. - The perfect states of Keratinomyces ajelloi Vanbreuseghem, Trichophyton terrestre (Durie): Frey and Microsporum nanum Fuentes. Sabouraudia, 1: 49-57, 1961.

17. ENGLISH, M.P. \& MORRIS, P. - Trichophyton mentagrophytes var. erinacei in hedgehog nests. Sabouraudia, 7: 118-121, 1969.

18. FERNANDES, N.C.; AKITI, T. \& BARREIROS, M.G.C. - Dermatophytosis in children: study of 137 cases. Rev. Inst. Med. trop. S. Paulo, 43: 83-85, 2001.

19. GENTLES, J.C. \& SCOTT, E. - Superficial mycoses in the West of Scotland. Scott. med. J., 26: 328-335, 1981

20. GEORG, L.K. - Ecology and diagnostic problems of fungal zoonoses. Indian med. Surg., 33: 308-310, 1964

21. KANE, J. - The biological aspects of the Kane/Fisher System for identification of dermatophytes. In: KANE, J.; SUMMERBELL, R.; KRAJDEN, S.; SIGLER, L. \& LAND, G. Laboratory handbook of dermatophytes. A clinical guide and laboratory handbook of dermatophytes and other filamentous fungi from skin, hair, and nails. Belmont, Star Publishing Company, 1997. p. 95-100.

22. KANETO, C.N.; CALIL, E.M.B.; VILLALOBOS, E.M.C. et al. - Epizootia de "tinha" em bezerros devida a Trichophyton rubrum. Biológico, 58: 17-20, 1996.

23. KEMNA, M.E. \& ELEWSKI, B.E. - A United States epidemiologic survey of superficial fungal diseases. J. Amer. Acad. Derm., 35: 539-542, 1996. 
24. KRAJDEN, S. - Dermatophytes: epidemiology and clinical features. In: KANE, J . SUMMERBELL, R.; KRAJDEN, S.; SIGLER, L. \& LAND, G. Laboratory handbook of dermatophytes. A clinical guide and laboratory handbook of dermatophytes and other filamentous fungi from skin, hair, and nails. Belmont, Star Publishing Company, 1997. p. 5-32.

25. KROWCHUCK, D.P.; LUCKY, A.W.; PRIMMER, S.I. \& McGUIRRE, J. - Current status of the identification and management of tinea capitis. Pediatrics, 72: 625-631, 1983 .

26. KUSHIDA, T. \& WATANABE, S. - Canine ringworm caused by Trichophyton rubrum; probable transmission from man to animal. Sabouraudia, 13: 30-32, 1975.

27. KWON-CHUNG, K.J. \& BENNETT, J.E. - Medical Mycology. Philadelphia, Lea \& Febiger, 1992. p. 121.

28. LIMA, E.O.; PONTES, Z.B.V.S.; OLIVEIRA, N.M.C. et al. - Freqüência de dermatofitoses em João Pessoa, Paraíba, Brasil. An. bras. Derm., 74: 127-132, 1999.

29. LONDERO, A.T. \& RAMOS, C.D. - Agentes de dermatofitoses humanas no interior do Estado do Rio Grande do Sul no período 1960-1987. An. bras. Derm., 64: 161-164, 1989

30. LOPES, J.O.; ALVES, S.H. \& BENEVENGA, J.P. - Dermatofitoses humanas no interior do Rio Grande do Sul no período 1988-1992. Rev. Inst. Med. trop. S. Paulo, 36: 115-119, 1994.

31. LOPES, J.O.; ALVES, S.H.; KREBS, R.C. \& KREBS, A.M. - Epidemiologia das dermatofitoses nos usuários da piscina do centro de educação física da Universidade Federal de Santa Maria: nota preliminar. Rev. Ass. méd. Rio Gr. Sul, 36: 120-121, 1992.

32. LOPES, J.O.; ALVES, S.H.; MARI, C.R.D. et al. - A ten-year survey of tinea pedis in the central region of the Rio Grande do Sul, Brazil. Rev. Inst. Med. trop. S. Paulo, 41: 75-77, 1999.

33. LOPES, J.O.; COSTENARO, C. \& BENEVENGA, J.P. - Dermatofitoses por Trichophyton tonsurans no interior do Rio Grande do Sul. Rev. Ass. méd. Rio Gr. Sul, 39: 255 $257,1995$.

34. MANZANO-GAYOSSO, P.; MENDEZ-TOVAR, L.J.; HERNANDEZ-HERNANDEZ, F. \& LOPEZ-MARTINEZ, R. - Dermatophytosis in Mexico City. Mycoses, 37: 49$52,1994$.

35. MARAKI, S. \& TSELENTIS, Y. - Dermatophytosis in Crete, Greece, between 1992 and 1996. Mycoses, 41: 175-178, 1998.

36. MATTÊDE, M.G.S.; COELHO, C.C.; MATTÊDE, A.F.; PERIN, F.C. \& PALHANO Jr., L. - Etiologia das dermatofitoses em Vitória (ES). An. bras. Derm., 61: 177-182, 1986.

37. MORIELLO, K.A. \& DeBOER, D.J. - Fungal flora of the coat of pet cats. Amer. J. vet. Res., 52: 602-606, 1991.

38. NASCIMENTO, A.M. - Caracterização morfológica, bioquímica e molecular de isolados patogênicos de Trichophyton. Ribeirão Preto, 1997. (Dissertação de Mestrado - Departamento de Genética da Faculdade de Medicina de Ribeirão Preto da Universidade de São Paulo).
39. PALACIO, A.; CUÉTARA, M.S.; VALLE, A. et al. - Cambios epidemiológicos observados en un decenio en las dermatofitosis del hospital universitario "12 de Octubre" de Madrid: nuevas especies emergentes. Rev. iberoamer. Micol., 16: 101-106, 1999.

40. PECHER, S.A. \& BORRAS, M.R.L. - Prevalência de micoses superficiais na população adulta da fronteira Brasil-Colômbia. Med. cut. ibero-lat.-amer., 14: 333-340, 1986.

41. PECHER, S.A.; CASTRO, G.B. \& BORRÁS, M.R.L. - Prevalência de micoses superficiais em escolares de localidades da região amazônica ocidental (fronteira Brasil-Colômbia). An. bras. Derm., 57: 13-18, 1982

42. PROENÇA, N.G.; MASSETI, J.H.; SALEBIAN, A. \& CUCÉ, L.C. - Flora dermatofítica e condições socioeconômicas. An. bras. Derm., 50: 183-196, 1975.

43. RANGANATHAN, S.; BALAJEE, A.S. \& RAJA, S.M. - A survey of dermatophytosis in animals in Madras, India. Mycopathologia (Den Haag), 140: 137-140, 1997 1998.

44. REBELL, G. \& TAPLIN, D. - Dermatophytes. Their recognition and identification. Coral Gables, University of Miami Press, 1979. p. 1-62.

45. RIPPON, J.W. - The changing epidemiology and emerging patterns of dermatophyte species. In: McGINNIS, M.R., ed. Current topics in medical Mycology. New York, Springer-Verlag, 1985. v.1, p. 208-234.

46. RUIZ, L.R.B. \& ZAITZ, C. - Dermatophytes and dermatophytosis in the city of São Paulo, from August 1996 to July 1998. An. bras. Derm., 76: 391-401, 2001.

47. SANTOS, J.I.; NEGRI, C.M.; WAGNER, D.C. et al. - Some aspects of dermatophytoses seen at University Hospital in Florianópolis, Santa Catarina, Brazil. Rev. Inst. Med. trop. S.Paulo, 39: 137-140, 1997

48. SINSKI, J.T. \& KELLEY, L.M. - A survey of dermatophytes isolated from human patients in the United States from 1982 to 1984. Mycopathologia (Den Haag), 98: 35-40, 1987.

49. SMITH, J.M.B., RUSH-MUNRO, F.M. \& McCARTHY, M. - Animals as a reservoir of human ringworm in New Zealand. Aust. J. Derm., 10: 169-182, 1969.

50. STENWIG, H. \& TAKSDAL, T. - Isolation of Epidermophyton floccosum from a dog in Norway. Sabouraudia, 22: 171-172, 1984

51. TAPLIN, D. - Superficial mycoses. J. invest. Derm., 67: 177-181, 1976.

52. TERRENI, A.A.; GREGG Jr., W.B.; MORRIS, P.R. \& Di SALVO, A.F. - Epidermophyton floccosum infection in a dog from the United States. Sabouraudia, 23: 141-142, 1985.

53. WEITZMAN, I. \& SUMMERBELL, R.C. - The dermatophytes. Clin. Microbiol. Rev., 8: $240-259,1995$

54. WILMINGTON, M.; ALY, R. \& FRIEDEN, I.J. - Trichophyton tonsurans tinea capitis in the San Francisco Bay area: increased infection demonstrated in a 20-year survey of fungal infection from 1974 to 1994. J. med. vet. Mycol., 34: 285-287, 1996.

55. ZAIAS, N. - Onychomycosis. Arch. Derm., 105: 263-274, 1972.

Received: 14 November 2002

Accepted: 18 September 2003 